\title{
Evaluating irreversible social harms
}

\author{
A. J. K. Pols ${ }^{1}$ H. A. Romijn ${ }^{1}$
}

Published online: 28 January 2017

(c) The Author(s) 2017. This article is published with open access at Springerlink.com

\begin{abstract}
In this paper we investigate how irreversible social harms should be evaluated from an ethical perspective. First, we define a general notion of irreversibility, drawing on discussions in ecology and economics. This notion is relational in the sense that "irreversibility" is always "irreversibility for a certain party". We also note that a change may be more or less difficult to reverse, with full reversibility and irreversibility as two extremes. Second, we examine what can make an irreversible change a harm, and why these kinds of harms have particular ethical significance. Here we draw on discussions from ethics, particularly regarding the capability approach. We also show how our notion of irreversibility connects to, and can add to, discussions in the fields of development studies and disaster management, particularly on the concept of resilience. Third, we suggest how potentially irreversible harms can be recognised and dealt with in policymaking. Finally, we show how our framework can be applied by evaluating the land acquisition process of two biofuel producers in Tanzania.
\end{abstract}

Keywords Irreversibility · Socio-ecological systems · Capability approach · Biofuels · Resilience

\section{Introduction}

In discussions on the environment and global climate change, a special place is often reserved for changes that are considered to be irreversible, such as species extinction or the melting of the West Antarctic ice sheet. Such changes are considered to be ethically problematic if they lead to harm because of their structural nature. Though conceptions of

\section{A. J. K. Pols}

A.J.K.Pols@tue.nl

1 School of Innovation Sciences, Eindhoven University of Technology, IPO 1.09, P.O. Box 513, 5600 MB Eindhoven, The Netherlands 
irreversibility differ, they generally require that a change has a long duration, is impossible or extremely costly to revoke and destroys or impairs something that cannot be substituted (Verbruggen 2013). Any harm caused by an irreversible change can thus be considered to be permanent. This has led to the incorporation of the notion of irreversibility in some versions of the precautionary principle, for example, its explication in the 1992 UN Rio Declaration:

'In order to protect the environment, the precautionary approach shall be widely applied by States according to their capabilities. Where there are threats of serious or irreversible damage, lack of full scientific certainty shall not be used as a reason for postponing cost-effective measures to prevent environmental degradation.' (UN 1992, Principle 15).

It is noteworthy that, while the 1992 UN Rio conference was on the topic of environment and development, the irreversible damage alluded to in this principle is only applied to environmental degradation resulting from human action. Indeed, the concept has mostly been applied with regard to changes in the environment (Adger et al. 2009), yet there seems to be good reason to apply it to changes that could damage or hamper social communities as well. The goal of much current development aid is "capacity building", or bringing about structural social changes for the better-but this implies that there is also the possibility for "capacity destruction" or structural social changes for the worse. Examples of this could be cultural genocide or ethnocide involving the large-scale destruction of cultural heritage, but also the destruction of ecosystems that play a vital role in meeting a community's needs, upsetting its social structure. The latter is particularly problematic for poor communities, who tend to be more dependent on the ecosystems and natural resources in their immediate surroundings than richer communities, who have better access to (inter)national markets (Martinez-Alier 2005). Indeed, fields such as political ecology and socio-ecological systems analysis stress that the sustainable development discourse following the Rio conference has failed to recognise that ecology and policy/social aspects are always intertwined, nor has it resulted in the tough decisions necessary to promote truly sustainable development and stop the marginalisation of the poor in resource conflict situations (Bryant 1998; Stafford-Smith et al. 2016). Similarly, the issue of how to deal with irreversible losses and damage, whether ecological or social, has only recently emerged on the UNFCCC's agenda next to mitigation and adaption and is politically hotly contested (Vulturius and Davis 2016).

Intuitively, irreversible changes for the worse seem to have a particular ethical significance. At the same time, irreversibility is underconceptualised in ethics (an exception is Humphrey 2001), making it unclear how an irreversible harm should be valued compared to a reversible harm, and why. This is not only a theoretical problem for ethics, but also a practical problem for policy-makers. While proposals have been put forward to value irreversible harm in ecosystems, for example through the notions of ecosystem services (MEA 2005) and tipping points (IPCC 2014), structural damages to especially social institutions cannot be quantified easily (Adger et al. 2009), and risk assessments, costbenefit analyses or sustainability assessments of policy measures often cannot handle evaluation of irreversible social changes well. Attempts by economists to assign prices to so-called non-market values of socio-ecological systems (e.g. Costanza et al. 2014) capture this problem only imperfectly, since not everything that counts can be counted. ${ }^{1}$ This

1 Michael Sandel (2012) has even defended the stronger point that not everything that counts should be
counted (economically), as this implies that there is a certain price for which it is acceptable to own, and 
applies especially to so-called non-use values, such as protection of communities against natural hazards, the value of beautiful views, the sound of flowing water or spiritual or religious associations with aspects of the natural environment (van der Horst and Vermeylen 2011), values that tend to be marginalised by mainstream economics but that are central to branches of environmental ethics such as the deep ecology movement (e.g. Næss 1973).

The field of political ecology offers a more promising start to investigate the ethics of social irreversibility: political ecologists tend to have a keen awareness of the relations between society and ecology in socio-ecological systems (e.g. Blaikie and Brookfield 1987), how values and perspectives on problems differ between local and global levels (Peet and Watts 1996; Stott and Sullivan 2000) and how power inequalities on and between those levels can lead to social marginalisation. However, although political ecology is strongly driven by normative ideals and the need to expose moral problems, it tends to be a descriptive mode of inquiry (Franklin and Downing 2004). As such, it focuses more on exposing the drivers of marginalisation and social exclusion than on identifying ethically salient aspects of impacts or determining what would be a proportionate political response. For example, Smith and Stirling (2010) criticise political ecology for conflating shock and stress effects, where shocks are short-lived disturbances of a socio-ecological system (e.g. a drought) and stresses long-term pressures (e.g. a drier climate) that require different kinds of policy responses. Yet Smith and Stirling do not explicate the ethical import of their distinction, or whether the irreversibility of shocks and stresses matters (remember that a long duration is only one of three aspects that makes a change less reversible), which is relevant when considering policy responses. Thus, the need remains for a normative analysis of socially irreversible changes.

A first step towards remedying the situation would be to investigate the notion of irreversibility in the social world and what it means for a change to constitute an irreversible social harm. This can help explicating these changes and increasing awareness about their importance, allowing for a more inclusive evaluation. Our research question in this paper is thus: How should we evaluate irreversible social changes from an ethical perspective?

We address this question in the following way. In the section on "Irreversible harm", we examine what an irreversible change $i s$, as conceived of in the literature on ecology and ecological economics. Building on these conceptions, we define a relational notion of irreversibility in social changes, which assumes that a change is always (ir)reversible for someone. We also discuss when irreversible changes become harms. In the section on "Irreversible harm in ethics", we examine what makes irreversible harms ethically problematic: though we will focus on the "extreme" case of irreversibility to get a clear view of the resulting ethical problems, we trust that our analysis also makes clear that reversibility is often a matter of degree, and why harms with low reversibility are more problematic than similar harms with high reversibility. Furthermore, we link our ethical analysis to work in political ecology and development studies. This leads to recommendations in the section on "Irreversible harm in policy-making" on how potentially irreversible harms could be dealt with in policy-making. In the section on "Irreversible social harms in practice: a case study" we test our proposal on a case study of biofuel developments in Tanzania. Following the publication of the EU's 2009 Renewable Energy

Footnote 1 continued

thus destroy, neglect or degrade entities that are intrinsically valuable. Spash (1997) has shown that this implication is not acceptable for a significant part of society. 
Directive (EU RED; EC 2009) and its ambitious renewable energy target for the transport sector, various projects based on different business models were set up in many tropical countries, including Tanzania, in order to produce biofuels for export to Europe. Although their adverse social risks and impacts have been subject to review (e.g. van der Horst and Vermeylen 2011; Hodbod and Tomei 2013; Hodbod et al. 2015), the issue of (ir)reversibility has remained implicit. For instance, Hodbod et al. (2015) classify winners and losers from biofuel development projects but do not systematically assess the degree of permanence of the social impacts. We examine how these activities have impacted land use rights and smallholder farming practices, among others; whether the negative social impacts from these changes are more or less difficult to reverse; whether this has been adequately considered by the initiators of the change; and we give policy recommendations based on our framework.

\section{Irreversible harm}

\section{What is an irreversible change?}

Irreversible changes are generally acknowledged to give rise to long-lasting effects; are difficult to undo/have high revoking costs; and lead to the loss of substances or processes that are difficult to substitute (Verbruggen 2013).

A conceptual puzzle that we want to get out of the way first is how common irreversible changes are. In one sense, all changes are irreversible because each change takes time and the flow of time cannot be reversed. In another sense no change is irreversible because the effects of each change can in principle be undone, given enough time, energy and resources (cf. Humphrey 2001). We propose a pragmatic solution to this puzzle, which is to make reversibility relational, that is, the degree to which a change is reversible depends fundamentally on the capacities, values and resources of those affected. This brings reversibility into the social realm and makes it easier to establish per case what would count as "lasting long" or "being difficult to undo". For example, for the well-being of a community it does not matter whether the rapid erosion of their fertile soils is in principle or physically reversible, or whether the effects are not long-lasting on a geological timescale: it matters whether it is reversible for them on a human timescale.

Adopting a relational conception of reversibility means that few changes will be either fully reversible or irreversible. These are rather two extremes of a scale on which changes can be ordered according to their degree of reversibility: some changes are more reversible (require less time, effort, etc., to undo) than others. ${ }^{2}$ This does not imply that this scale is a smooth slope from reversibility to irreversibility: much as with changes to the climate system (IPCC 2014), there might be tipping points where changes become much harder to reverse. One tipping point would be where individuals cannot reverse changes anymore and communities have to step in. Our focus on communities, though, means that the most salient tipping point for us would be the point where a community affected by a change does not have the time or resources itself to reverse it, though other parties (national governments or international organisations) might still be able to do so, e.g. through finance or technology transfer (cf. Vulturius and Davis 2016).

One more conceptual point needs to be addressed before we proceed to analysing when an irreversible change is a harm, and this relates to the issue of substitution. A non-

\footnotetext{
${ }^{2}$ We thank an anonymous reviewer for suggesting this.
} 
relational definition would run into the conceptual puzzle again here. In one sense, nothing is substitutable because every entity is unique: if I break your escargot tongs and buy you new ones, I have not strictly reversed the effects of my action since your new escargot tongs are not your old ones. Yet in another sense everything that has a particular function or role in a wider system is functionally substitutable: the new escargot tongs are not the old ones, but they are a functional substitute. The idea of functional substitution is present in policy-making as well: it is for example core to the EU No Net Loss initiative, which allows for the destruction of ecosystems and the "commodification of nature" as long as the resulting biodiversity loss is "offset" by preserving or increasing biodiversity elsewhere. This idea has been criticised on practical grounds (e.g. Quétier et al. 2014), but its ethical acceptability is contestable as well. For while most people value escargot tongs only for their functional value, nature is valued in many ways, with regard to use (e.g. for its aesthetic, spiritual, educational and recreational value, MEA 2005), and intrinsically, just for being there (Spash 1997; McShane 2007). This does not imply that the destruction of plants, animals and whole ecosystems can never be justified, but rather that "offsetting" their destruction by functional substitution does not necessarily bring the moral scales back into balance for a certain community. Much as giving birth to one baby does not "morally offset" or "reverse" the murder of another, communities might object to the destruction of sacred groves, ancestral grave sites, art works (Benjamin 1968), etc., because they value those entities intrinsically and therefore, they cannot be properly replaced by planting a new grove, creating a new gravesite or making a replica of the art work. It is this ethical concern that a focus on irreversibility in terms of system functions threatens to miss, whether the unit of analysis is a physical (Verbruggen 2013) or socio-ecological (Walker et al. 2004) system. Yet this concern is at the same time very relevant for communities that often have strong and enduring ties to their place of habitation.

\section{When is a change a harm?}

Irreversible changes, like any changes, are not necessarily harms. Indeed, they can be beneficial, such as education, or morally neutral. Likewise, irreversible changes do not always involve destruction but can also involve alteration or creation, and this can have both positive and negative effects. The creation of nuclear waste would be an example of an event of creation that would count as an irreversible harm. While in this paper we mostly examine destructive events, our analysis applies as well to alteration and creation. Before proceeding we briefly go into the nature of harm to better recognise when a change counts as a harm.

Though there is discussion in the philosophical literature on what "harm" is (e.g. Hanser 2008) in this paper we will adopt Feinberg's (1984) notion of harm, which states that harming someone is wrongfully setting back their interests. Here, setting back an interest means putting it in a worse condition than it would otherwise have been in. For Feinberg, interests include welfare interests, meaning everything that is minimally needed for living a physically and mentally healthy life. And what makes an action wrongful towards some person is (a) that it is an action; (b) that it is done with the intention to set back that person's interests, or done with negligence regarding that person's interests; (c) that it violates that person's rights; and (d) that there is no moral justification or excuse for the action. Feinberg defines rights here as valid claims that one can make either against specific individuals (for assistance, compensation, etc.) or against the state (also for assistance, compensation, etc., but moreover for the legal enforcement of valid claims). 
Injuring or killing someone is clear example of harm, but taking away land use rights or land access on this account would count as a harm just as well.,

Note, though, that from the fact that a change would be a harm does not follow that it should be prevented at all costs. For both Feinberg (1984) and Mill (1859/1961), for example, it would at best play a role in justifying intervention of the state in the (potentially harmful) activities of individuals.

If we look at international rights treaties, everyone is entitled to "the realization (...) of the economic, social and cultural rights indispensable for his dignity and the free development of his personality" (Universal Declaration of Human Rights, Article 22), and to "freely participate in the cultural life of the community" (ibid., Article 27). In addition, treaties such as the International Labour Organisation Convention No. 169 reserve strong rights for indigenous and tribal peoples to preserve their cultures, institutions and environment against outside influences. It is thus legally perfectly possible that the destruction of a social or cultural institution or part of the ecosystem on which that community depends counts as a rights violation, and therefore, as a harm if it is done intentionally or carelessly.

\section{Irreversible harms in ethics}

When it comes to ethically evaluating systems, the most prominent approach is probably the normative side of the capability approach that has elaborated on the capabilities that people need to have in order to do and to be what they have reason to value (e.g. Sen 1992; Nussbaum 2000). Note that this conception of capabilities resembles Feinberg's welfare interests. This enables one to evaluate how systems, whether socio-technical, socio-ecological or otherwise, affect human well-being by investigating how they affect human capabilities. To give two other examples, in the philosophy of technology, Illies and Meijers (2009) have called sets of possible actions "action schemes", and argue that we have both the responsibility to perform morally right actions and bring morally right action schemes into existence. And in the field of global justice Young $(2004,2006)$ has evaluated structurally unjust systems and our responsibility for changing them. Her prime example is the global apparel industry, where the status quo is itself morally problematic and should be departed from. Common to all these approaches is a moral evaluation of sets of options for action. These sets are shaped by intentional, social and physical factors, and agents can alter the sets of options of other agents, for better or worse.

Establishing evaluative criteria for what makes one set of options better than another is no simple task. Intuitively, one could think that having more options for action is better, but this is not always the case (Peterson and Spahn 2011), especially if those options for action enable the large-scale destruction of humans and the environment (Jonas 1979/ 1984). From our examples, the capability approach has the most extensive account of what capabilities we need to have to be able to achieve well-being. Nussbaum (2000) has drawn up a list of capabilities she thinks are needed for flourishing, while Sen (2005) maintains that drawing up such a list is the purview of society rather than philosophers. For the

\footnotetext{
3 We assume in this paper that there is a meaningful sense in which we can talk about communities being harmed or wronged as well as flourishing, gaining capacities, etc.

${ }^{4}$ Note that as a political philosopher Feinberg's idea of rights [condition (c)] is dependent on legal systems, though condition (d) keeps open the possibility that a violation of legal rights could be justified in some circumstances. Nevertheless, Feinberg's definition of harm is close to that of Mill's (1859/1961), though for Mill, harms are set-back of interests that can, but do not have to be, wrongful.
} 
purposes of this paper we remain agnostic about precise specifications and will simply follow the capability approach in assuming that one set of options is better than another if it better enables the agent or community to survive and flourish.

We can now tie the concepts of irreversible changes and harm together and give a reasoned judgement on why irreversible harms are problematic. Irreversible harm to a community is a change that has long-lasting effects; that is difficult to undo or has high revoking costs; that leads to the loss of substances or processes that that community considers difficult to substitute and that it has reason to value; and that wrongfully makes that community worse off than it would otherwise have been. The core ethical problem in here is that such a change structurally impoverishes the set of options available to a community to survive and flourish (cf. Hillerbrand and Peterson 2014).

From a systems perspective, one particularly insidious consequence of irreversible harms is that they often leave people and communities worse off in their capacity to resist, adapt to or mitigate the effects of further (irreversible) harms. Irreversible harms may also affect the reversibility of other harms. For example, if some community suffers a structural financial setback, the threshold for what counts as "high revoking costs" for them lowers. This means that harms with high reversibility might become harms with low reversibility, not because the magnitude of the harm has changed, but because the capacities of the community have changed. In the socio-ecological systems literature, this is also conceptualised as a loss of resilience of the socio-ecological system to which the community belongs.

Though couching issues in terms of resilience has much appeal in the fields of study and practice of development studies and disaster management, there is considerable ambiguity about the meaning of the term, which impedes sound strategy design for improving it. For example, Manyena (2006) found no less than twelve distinct definitions of resilience, revealing disagreement even over whether it refers to processes or outcomes (see also (Baggio et al. 2015) for a citation network analysis of resilience concepts). Here, we consider resilience to indicate the amount of change a system can undergo while retaining its basic structure and functioning (Walker et al. 2004). Resilience, like reversibility, thus comes in degrees, where generally speaking changes in very resilient systems will be easier to reverse than changes in systems that have little or no resilience. ${ }^{5}$ If some harm irreversibly damages this capacity for resilience, the affected system will be less able to recover from further harms on its own or to reorganise into another state beneficial to humans, increasing the likelihood of further losses of resilience, and so on.

In cases where the initiator of the harm is another party than that most harmed by the irreversible change, this can lead to situations of what Young $(2004,2006)$ calls structural injustice. Young defines this in the following way: "Structural injustice exists when social processes put large categories of persons under a systematic threat of domination or deprivation of the means to develop and exercise their capacities, at the same time as these processes enable others to dominate or have a wide range of opportunities for developing and exercising their capacities" (2006, p. 114). Structural injustices are particularly hard to rectify, as those parties who have most to gain by changing the system have no capacities to do so, while those who do have these capacities (and thus most responsibility) have the strongest incentives to maintain the system. In socio-ecological system terms, this could be

\footnotetext{
5 Note, though, that as socio-ecological systems are dynamic, a reversal here does not necessarily mean a simple transition back from an equilibrium to the previous equilibrium. Rather, the system can recover by going through an adaptive cycle or reorganising itself into an alternate form that is at least as beneficial to humans as its previous form.
} 
conceived of as one system in a rigidity trap (that of the dominators/beneficiaries) and another system in a poverty trap (that of the suppressed/deprived) reinforcing each other's pathological state (cf. Allison and Hobbs 2004). Young gives the example of the global apparel industry, in which consumers and major brands benefit from sweatshops and child labour in developing countries. Allison and Hobbs' description of the agricultural system in Western Australia also hints at structural injustices, as they identify global markets and macroeconomics as contributing to the degradation of the Western Australian socio-ecological system.

This concern with structural injustice is echoed strongly in development studies literature, where researchers have observed that the production and reproduction of poverty and inequality in income and wealth over long periods of time is closely connected to processes of adverse incorporation and/or social marginalisation. Some authors go so far as to say that there are causal relations running from the latter to the former, or even a circular dynamic in which adverse incorporation leads to poverty and income inequality, which increases vulnerability for adverse incorporation, etc. (Smith 2007; Hickey and du Toit 2007; Phillips 2013). Those authors claim that the existence of this causality or circularity is key to understanding how certain groups or individuals are kept poor even in contexts characterised by economic growth and accumulation. Yet, no explicit notion of reversibility has been used in this discourse, so this paper could be valuable for development studies researchers and practitioners by for example helping to establish which factors make the reproduction of poverty less or more reversible.

The paper can also feed another currently popular discourse in the field of disaster management that emphasises the need to address risk of loss of resilience of people and communities after experiencing major shocks. Resilience in this field is interpreted broadly as the ability of communities to maintain their core values or assets through addressing non-core elements of their existence, such as ability to maintain food security (core value) by substituting rain-dependent crops (non-core element) for more drought-resistant crops in response to increasingly erratic weather patterns. In this interpretation, resilience thus refers to a system's ability to alter non-essential attributes - to adapt in order to keep functioning (Manyena 2006), which is very similar to Walker's concept discussed above.

Another important point of linkage between our preceding ethical discussion and more recent developments in the conceptualisation of resilience in development and disaster management studies is that development researchers and practitioners alike have widely advocated policies and strategies that are reminiscent of the capability approach. For example, the focus on systems when defining resilience in a developing context has been criticised, as this veils the agency of the people who are part of the system, and thus issues of power, democracy, etc. Moreover, resilience tends to be framed as morally good, where it is really a neutral concept (Béné et al. 2014; Brown 2014). Depending on circumstances, resilience can also impede much-needed structural changes, e.g. to our fossil fuel-reliant energy system (Smith and Stirling 2010). Béné et al. (2015) seek to repair these shortcomings by redefining resilience as the capacity to avoid long-lasting adverse development consequences (e.g. loss of well-being), which can be increased by strengthening the ability of households or society to make meaningful choices. There is a clear parallel here with our concept of irreversible harm (though Béné et al. focus on the long duration rather than also on issues of substitutability and revoking costs): the concepts of resilience and irreversible change are both recognised to be morally neutral, and a link needs to be made to harm or well-being to properly evaluate changes. And both concepts focus on human agency and changes to our ability to choose or the options for action available to us. However, where irreversible harm looks at the structural impoverishment in terms of 
decision-making capacities and capabilities, development and disaster management recommendations focus on the strengthening of capacities and capabilities of local people to gain or maintain some degree of local control over the nature and direction of externally driven change processes that affect them. Key elements in such strategies are for example stimulating engagement, partnership, collaboration and trust building (Norris et al. 2008).

\section{Irreversible harms in policy-making}

In the section on "Irreversible harms in ethics" we have established why irreversible harms are ethically relevant. Specifically, they can structurally degrade the set of options for action available to a community to survive and flourish. This is not only problematic in itself, but also because it can lead to loss of resilience, making it more difficult for the community to withstand, reverse or recover from further harms. Furthermore, it can lead to structural injustice, where the systems that cause irreversible harms to some are maintained by others who derive structural benefits from them.

In practice, cultural and social changes and the experienced world in general are "systematically undervalued" (Adger et al. 2009, p. 349) by current policy evaluation mechanisms such as cost-benefit analysis, for qualitative changes are difficult to capture using quantitative methods. ${ }^{6}$ For this reason, they are also hard to incorporate adequately in quantitative sustainability assessments. In this section we propose a practical way to incorporate irreversible social harms in political decision-making and deal with them.

Basically, our proposal is that due to the potential severity of irreversible harms, no policy that is expected to lead to social harms that are irreversible should ever be implemented. Of course, following Feinberg, if a policy can otherwise be morally justified it would not count as a harm, but a justified set-back of interests, even if this set-back is irreversible. Nevertheless, due to the potential severity of irreversible harms, the justification should be very strong. This proposal is in line with such high-level policy documents as the Universal Declaration of Human Rights, the UN Sustainable Development Goals and more specifically by the UN guiding principles on extreme poverty and human rights, which state that "No policy, in any area, should exacerbate poverty or have a disproportionate negative impact on persons living in poverty". 7

Sources of justification of irreversible set-backs of interests may include, but are not limited to informed consent and remedying structural injustices. We deal with each of those in turn.

A community can give informed consent to an irreversible set-back of interests. This may be because it is self-inflicted, not recognised by that community as a set-back of interests or because the community has decided that the benefits to be gained outweigh the irreversible costs.

While free, informed consent is commonly accepted, especially in medical ethics, as a good justification for interventions that may carry risk or have harmful side effects, a few caveats are in order. First, it should be clear that the community has the capacities to make an independent evaluation of the possible negative and positive effects of a policy, lest it

\footnotetext{
${ }^{6}$ Cost-benefit analysis as an aid in policy-making has received other criticisms as well, see e.g. Murphy and Gardoni (2007).

${ }^{7}$ Foundational principle A. http://www.ohchr.org/Documents/Publications/OHCHR_ExtremePovertyand HumanRights_EN.pdf. Accessed 12 January 2017.
} 
agrees to a policy the consequences of which it cannot oversee (see the section on "Irreversible social harms in practice: a case study" for an example).

Second, the process of community decision-making should be legitimate, lest corrupt or incompetent community leaders make decisions for rather than on behalf of the community (see also the section on "Irreversible social harms in practice: a case study"). A complication both theoretical and practical here is that irreversible harms will also make future generations of that community worse off, who by definition cannot participate in the decision-making process. Third, there are problems with exporting the concept of informed consent from a clinical/individual to a policy/community context (Hansson 2006), such as difficulty with identifying the "stakeholder community", the focus on acceptance of a proposal rather than participation in the procedure and the question of what community consensus should meanis it a majority vote, should everyone agree or is it something else? ${ }^{8}$

With regard to making a trade-off, this may be acceptable if the irreversible set-back of interests is traded off against one or more irreversible benefits, e.g. by trading formal land rights for the creation and maintenance of a school and hospital in a community. Note that in this case what is lost is not substituted, but compensated for. If the irreversible set-back of interests is traded off against a temporary benefit, e.g. a community receiving a lump sum in return for their formal land rights, this remains ethically problematic. The community's set of options for action is structurally impoverished, and unless the lump sum will be used to invest in structural improvements, its benefits will be short-lived, after which the community's set of options for survival and flourishing will remain impoverished. In particular, important with regard to trade-offs when irreversible harms are involved is that not just values have to be weighed against each other: they also have to be weighed against the loss of options for action that the community might, now or in the future, have reason to value. Though such an evaluation is a complicated exercise, it has precedents in economics, for example in Bishop's (1978) safe minimum standard to supplement cost-benefit analysis, or Arrow and Fisher's (1974) observation that net benefits can be reduced if potentially irreversible harms are involved.

A second source of justification for an irreversible set-back of interests may be if it is inflicted to remedy a structural injustice (Young 2004, 2006). If systems are set up to structurally violate the rights of a group of people to improve the wealth of another group, dismantling those systems may be ethically acceptable or even obligatory, even if that entails irreversible set-backs of interests to those who used to benefit from them, as long as their basic rights are respected. For example, the EU recently set an upper limit on the percentage of biofuels that may be derived from food crops for transport energy. ${ }^{9}$ This would count as setting back the interests of producers of food crop-based biofuels as it limited their potential market. In this case, however, the set-back of interests was (partly) justified by the argument that the production systems of food crop-based biofuels lead to deforestation and higher food prices, and exacerbate climate change, all of which disproportionately affect poor rural communities in the global South. Hence, the set-back of interests was not wrongful and thus did not count as a harm.

A possible criticism of our proposal is that, in its current form, it offers little action guidance. It tells us what policy-makers may not do, but not what they should do instead.

\footnotetext{
${ }^{8}$ See the discussions in the field of responsible innovation on this topic (e.g. Blok 2014; Correljé et al. 2014). For more empirical work on biofuels and informed consent/stakeholder involvement issues, see e.g. Silva-Castañeda (2012), Hodbod et al. (2015).

9 http://www.euractiv.com/section/energy/news/eu-diplomats-agree-to-7-biofuels-cap/. Accessed 12 January 2017.
} 
Therefore, we offer two positive suggestions here. Our first suggestion would be to, whenever a policy would lead to irreversible social harms, amend that policy in order to not bring about harm, or, if that is impossible, to make the harm as reversible as possible. In practice, this would often mean addressing one of irreversibility's three components: long duration, high revoking costs or substitutability. Our second suggestion would be to explicitly take the (quasi-)option value ${ }^{10}$ of waiting and reducing uncertainty into account, both with regard to whether a change will be irreversible and with regard to whether a change will constitute a harm. While there can be value in "being the first" and loss in "missing the boat", there are also risks involved. Starting with small-scale experiments and slowly upscaling can be a good strategy for uncertainty reduction and identifying possible irreversible harms early on. If small-scale experimenting is not possible or feasible without introducing the risk of irreversible harms, this should lead to an implementation of the precautionary principle, which in this case may well entail a combination of uncertainty reduction and a proper sustainability assessment (but see the "Conclusions" section), implementing robust precautions and a wait-and-see approach to determine whether a new development has the potential to truly contribute to sustainable development or will be a short-lived hype.

\section{Irreversible social harms in practice: a case study}

In this section we show how our notion of irreversible social harms can be used to analyse policy and investor decisions and give ethical recommendations. As our focus we take the recent establishment of some large biofuels projects by foreign actors in poor developing countries, with the objective to grow biomass for western energy markets. Through many of these investments, local rural populations have been (at risk of being) dispossessed from their land and resources on which they depend for their livelihoods (e.g. Matondi et al. 2011; Cotula 2013; Cotula et al. 2008).

The phenomenon of transfer of lands from local communities towards commercial farming operations has been pervasive for a very long time, and biofuels have not even played a leading role in this process, historically speaking. However, their emergence is now contributing to increasing problems of land pressure due to the proliferation of competing resource uses. Still, this is not our main reason for focusing on biofuels. Our cases were part of a movement in which the investment drive and production themselves were very short-lived, whereas many of the local social impacts they caused show signs of persistence. Our cases are thus meant to highlight that even activities with little staying power can already have severe, possibly structural consequences for local people. Such impacts can be easily underestimated, because it is easily assumed that the withdrawal of the economic activities implies the possibility of reversal to the pre-intervention state. Therefore, cases in which that assumption does not hold can furnish powerful lessons for more socially responsible project assessment methodologies and policy governance in a future in which competition over land and land-based resources will only increase further, and short-lived investment hypes keep occurring frequently.

\footnotetext{
${ }^{10}$ In economics, the term option value is used to denote the value placed on private willingness to pay for maintaining or preserving a public asset or service, even if there is little chance that the individual will actually ever use it. One speaks of quasi-option value when the conventional cost-benefit framework used to analyse option values is expanded to take explicit account of possibilities of irreversible loss (or very high loss of replacement) of the asset or service in question. See e.g. Claude (1974), Arrow and Fisher (1974).
} 
Biofuel-induced "land grabbing" lately has been subject to intense scrutiny, and most of the material on which we base our case discussion is already in the public domain. We tried to use reports based on primary data as much as possible. We supplemented this by primary data collected by one of the authors during three visits to Tanzania during 2006-2011, including from personal observations of people in their living environment, semi-structured interviews with NGO representatives, investors, academics, and policymakers in the biofuel sector, and several conversations with the Dutch management staff of one of the projects discussed in this section (partly reported earlier in Romijn 2011). The main purpose in this paper is not to present substantial novel primary data as such, but rather to re-assess the available documentation in the light of the conceptual lens of irreversible social harm - an issue that has not been addressed systematically by the earlier biofuel literature.

Readers will note some similarity to earlier assessments of biofuel projects by political ecology researchers. This is because we need to assess in some depth the drivers of the impacts emanating from different socio-ecological scales-including such aspects as strategic interests, economic inequalities and power relations-in order to obtain a good insight into the extent to which certain impacts constitute social harms that are difficult to reverse. In particular, insights into how formal and informal institutions function in practice in a certain context cannot be obtained without such analysis. Thus, we see the relationship between political ecology and our own work as complementary and synergistic.

Modern-day land grabbing is being facilitated by a constellation of factors (e.g. Deininger and Byerlee 2011; Cotula 2013). In particular, a continued persistence of the neoliberal economic paradigm in world economic affairs has contributed to a widespread belief in the benefits of a development model for poor countries premised on western private-sector-driven investments for the purpose of building exports to western markets. There is a big role for the world's powerful international institutions to ensure that host governments observe "good governance" principles. De facto, these principles act to reduce the domestic policy space for governments of indebted poor countries (Wade 2003). "Good governance" is not an ideologically neutral concept (Baker 2015). Under its banner, frugal governmental involvement with the affairs of the private business sector and the pursuit of a business-friendly investment climate have been widely pushed, among other things through making the continued reception of international aid and debt relief conditional upon host governments' cooperation in this respect (Cotula et al. 2008).

In this climate, investments in biofuels in poor countries began to be promoted in the early years of the twenty-first century as a "package solution to energy security, environmental protection and rural development" (Widengård 2011, p. 51); in other words as "win-wins", in which both the investing company, and the host country with its people would reap benefits (Bergius 2012). In this view, there is abundant unused, idle and un(der)productive land that can generate more public value when utilised by commercial investors (Havnevik 2011). Another older strong development paradigm can also still be seen to influence important policy and business actors on the world biofuel scene: that of development-as-modernisation or developmentalism. In this paradigm, development is conceived as a top-down process initiated by elites, with its benefits gradually spreading downwards and outwards towards the "backward" peoples until the entire society has been enfolded into it (Arora et al. 2014; Schneider 2006). It is therefore hardly surprising that biofuel projects were initially welcomed; local people were assumed to become beneficiaries through the opening up of possibilities for modern wage work in economically depressed areas and participation in the market arena where they would be able to procure 
a much wider variety of goods and services than they would be able to obtain by eking out a marginal existence from the land through self-provisioning (Arora et al. 2014).

The biofuel investors that came to Tanzania entered a country with approximately 4 million peasant families, among whom poverty and malnutrition are high. Farming and nomadic herding are the principal economic activities (Maltsoglou and Khwaja 2010; WWF 2009; van Eijck et al. 2014). Most rural households tend to diversify their livelihood sources in order to decrease their vulnerability in case of crop failure or irregular weather conditions. Products from freely accessible common property resources are highly important in this scheme of things. A World Bank report estimates that between 25 and $50 \%$ of local people's "income" comes from such non-marketed resources (World Bank 2008).

In Kisarawe District, which was selected by Sun Biofuels, UK, marginal agriculture on poor-quality land was the main livelihood source for about $80 \%$ of the population consisting of approximately 3000 households. Much of the area was already in a degraded state because of the proximity of Tanzania's huge port city, Dar es Salaam, which generates an enormous demand for cooking charcoal-the major source of forest clearance. Local communities had great difficulties trying to manage their local natural resources (WWF 2009). Sun Biofuels negotiated a lease for 99 years for this land for the cultivation of close to 2000 ha Jatropha, an oilseed shrub.

Subsequent research among local villagers has noted many harms from this development: worst of all, Sun destroyed a local swamp that was a crucial water source for local people during dry months (note that local people do not have the resources to hire heavy earth-moving machinery and operators to dig the soil back up again). After the establishment of the plantation they had to walk up to $10 \mathrm{~km}$ (previously a 15-30 min distance) for their basic water needs, which adversely affected their agricultural productivity and their quality of life more generally, according to a survey among the local villagers conducted by Bergius (2012). Wages earned from plantation work proved so low that the money was insufficient to buy the provisions that were previously self-produced through subsistence activities. It proved impossible to combine a full-time wage job on the plantation with own-account farming (Kitabu 2012), but people also could not revert back to the old situation due to the loss of the land and water resources.

Monetary compensation was eventually paid by Sun, but not until after it was discovered that the district government had falsified certain papers that stated that the villagers had agreed to the land transfer (Schlimmer 2016). Eventually the central government was instrumental in arranging for the compensation, but it could not undo the land transfer. According to other sources, compensation valuation practices were aimed at minimising compensation values, and illiterate villagers had insufficient knowledge about their land rights and could not negotiate adequately. There was also considerable pressure put on them by a local MP who was much in favour of the project (Sulle and Nelson 2009). Sun is said to have misrepresented prospective benefits and played down risks (Bergius 2012). Sulle and Nelson reported on the basis of conversations with the villagers that they were not aware that they should have insisted on a formal contractual format, as they had never experienced such dealings before. They also did not know what kinds of contractual provisions were most important for safeguarding their rights and interests (2009). According to Bergius, villagers reported that Sun used strategic "divide and rule" tactics which played off the populations from different villages against each other. The company would argue in their negotiations with village $\mathrm{X}$ that village $\mathrm{Y}$ had already agreed to certain proposals, in order to put pressure on village $X$ to do the same (2012). 
Compensation was also promised (but only verbally) in the form of improved public infrastructure such as a better equipped maternity clinic. While in themselves beneficial, however, the services provided by these human capital assets are no direct substitutes for ecosystem services derived from land-based activities that are crucial for maintaining food security of local people, like beekeeping, charcoal making, hunting and medicinal and food plants gathering (World Bank 2008; Msuya et al. 2010). Moreover, the promises never materialised (Sulle and Nelson 2009).

Sun also included an ancient ancestral graveyard site into its plantation and subsequently forbade public access to it. According to the ethnographic research by Bergius, graveyards are always placed in the common village land, and related practices are deeply embedded in traditional culture and beliefs. The site in question was often frequented by local people. Some years later the access constraint was eased, but only with considerable effort from locally operating NGOs and helped by wide public journalistic exposure of the problem (2012).

Five years after starting the plantation, the Sun operations went bankrupt due to lack of profitability of Jatropha biodiesel, but the villagers were unable to revert back to their traditional way of life. A new foreign investor took over, which announced that it will develop a livestock ranch on the land. Substantial employment of local people is not foreseen and access problems remain.

The main implications in terms of social harms arising from these combined developments have been summarised in Table 1. As argued earlier, reversibility is often a matter of degree. We have acknowledged this by distinguishing a grey area between the two ends on a reversibility-irreversibility scale. However, we were unable to identify any harm that was easily reversible, given the difficult institutional context which includes: poorly educated villagers who are not aware of their rights versus a savvy and powerful western investor with recourse to professional legal aid; a district government with interests in attracting commercial investors; highly complex land transfer mechanisms and confusion over procedures among all parties involved (Schlimmer 2016); the very long terms allowed under the commercial lease; and the wider pressures put upon the government of Tanzania by powerful international institutions to adhere to foreign investor friendly "good governance".

While it has to be said that the classification and the scoring of the project impacts are subject to some inevitable subjectivity, the results for all the impacts clearly point towards serious reversibility problems.

The second case in focus is Bioshape from the Netherlands. In contrast to Sun, this investor targeted a remote coastal area (Kilwa) with plenty of so-called unused land. It planned to establish a Jatropha plantation of 81,000 ha. In the first instance it convinced local villagers to give up approximately 34,500 ha of their village land. According to both the villagers and the company, the land was not in current use by the local population and thus left them with sufficient resources for their day-to-day farming needs (Romijn 2011). However, problems began to be reported some time after the land lease took effect, drawing attention to loss of hunting grounds due to clear felling of forest (WWF 2009; Sulle and Nelson 2009; Chachage and Baha 2011; Valentino 2011). The Bioshape business plan came out into the open, and this added to public anxiety because it was found to include an estimated 200,000 to 800,000 cubic metres of valuable hardwood harvesting potential on its concession as its main income in the early years of operation, worth 50-150 million dollars (Valentino 2011). Those same grounds were now reported to be used by the local people for firewood gathering, charcoal making, medicinal plant gathering, etc., all of which were important for people's caloric intake or their broader livelihood. Poverty in the 
Table 1 Assessment of (ir)reversible social harms, case 1 (Kisarawe)

Type of impact Duration \begin{tabular}{l}
$\begin{array}{l}\text { Revoking } \\
\text { costs }\end{array}$ \\
\hline
\end{tabular}

1. Swamp destruction leading
to loss of livelihoods
(cultivation, livestock
rearing)
2. Land ownership loss and
restrictions of access, leading
to loss of cultural and
spiritual values (gravesites of
forefathers = home), feeling
of insecurity and
homelessness

3

3

3

2

3

3

homelessness

3. Loss of wage employment
after biofuel investor
Permanent effects due to structural loss of livelihood water resources; initial compensation through wage labour on plantation proved too little for too few and lacked long-term security

Company lease $=99$ years after which the land remains state owned, and it cannot be transferred back to the villages since there is no law in Tanzania that enables this (see case 2). Access to gravesites seriously impeded but some degree of access was later restored thanks to considerable pressure by external parties (NGOs, media). Unclear whether new burials are still allowed on the same site

Layoffs of wage workers due to Sun's bankruptcy and at the same time the impossibility to revert back to original way of life (due to impact \#1) or to start a new life elsewhere due to low one-time compensation. If attractive alternative employment could be offered, many locals would take this up (as they did when Sun arrived) in favour of going back to difficult traditional way of life.

Problem is the severe lack of alternative remunerative jobs in the area

Classification legend

Duration: 1 short, within a few months or years; 2 medium, within one generation; 3 long, beyond one generation, possibly permanent

Revoking costs: 1 low = manageable for community without help; 2 medium $=$ substantial, requiring some external help but not impossible to achieve; 3 high = practically unaffordable, requiring extensive external assistance which is only in theory possible to obtain

Substitutability: 1 high = community does not suffer notable loss of value; 2 medium $=$ community can cope but suffers losses that are hard to substitute for, which affect their well-being to some extent; 3 low $=$ community suffers significant loss of value and well-being - there are no suitable alternatives that can substitute for the losses 
region is high; $30 \%$ of people are reported to be either chronically food insecure or highly vulnerable to food insecurity (van Eijck et al. 2014).

Bioshape did not put pressure on local people; the villagers reported that they were always approached in a polite and respectful manner. The main problem in this case seems to have been naivety on the part of the Dutch owners and management team about the difficulties of the local social environment they were operating in, including problems such as complex and opaque land transfer procedures, local government officials trying to use the project for their own (whether personal or public) agendas and the huge difference in lifeworlds between the Dutch and the illiterate rural Tanzanian people in a backward district (Romijn 2011). For instance, Bioshape appointed a 1\% Tanzanian shareholder whose task it was to smooth the way for the project through the bureaucracy, with no ill intentions as such (ibid.). However, so it could happen that a compulsory Environmental Impact Assessment was officially approved by putting the name of a reputable scientist on its cover, without this individual's involvement in the study (Valentino 2011), and without the management and majority shareholders being aware that this had been done (Romijn 2011). Also, the permissions to start clear felling were issued by a Minister who did not have the jurisdiction to do so, whereas the Bioshape sustainability officer believed all permits to be in order (the Minister was later removed from office, after the discovery of a raft of other scandals) (Romijn 2011).

Similar issues lay behind problems with the inadequate compensation of community members for the reduction in commons access - a lump sum of US\$12/ha for a 99-year lease period (Sulle and Nelson 2009). Bioshape voiced their intention to pay adequate compensation (Romijn 2011), but reality worked out differently. The compensation paid by Bioshape entailed the permanent loss of all land rights for the villagers, since the land would revert permanently to the central government after that. When they were negotiating, the villagers were not aware of that fact (Valentino 2011). Most likely, the firm's representatives had assumed that the villagers were indeed aware, so they had not emphasised this in their communication. To make matters worse, the local district government took $60 \%$ of the compensation amount (Sulle and Nelson 2009). Bioshape had been requested to route its payments through the district government and had had no reason to question this procedure (Romijn 2011). It was said-later-that the district government had no legal right to take a share of the money, which it disputed. Whether legal or not, the action by the district government came as a nasty surprise to the villagers (Sulle and Nelson 2009). Some village communities both in Kisarawe and in Kilwa claimed that none of the agreed-upon compensation money ever reached them. Others did not even know what to do with their claim forms, and never received any money because they did not file any claims (Bergius 2012). And just like in the case of Sun, Bioshape also made verbalnot written-promises of upgraded public infrastructure, most of which did not materialise (Romijn 2011).

Villagers also pointed out that, to the extent the plantations had brought "mixed bags of goods and harms", the benefits were short term in nature, whereas the bads are enduring (Kitabu 2012). As it turned out, the benefits proved highly vulnerable to the vagaries of the global economic system that suffered a big implosion in 2008. In that same year both plantation firms withdrew due to bankruptcy induced by disappointing harvests, crashing world oil prices and inability to attract fresh finance from risk-averse banks. This left the villagers without their new wage jobs. The more than 300 casual workers working on the Bioshape plantation were fired from one day to the next without prior communication or compensation (Romijn 2011). The few who had employment contracts were kept on, but in the end they were not paid for the final six months of their contract (Romijn 2011). The 
villagers were left without their former land resources, and without the maternity clinic, school, improved road or water well they had been promised (Carrington 2011; van Eijck et al. 2014). In both the Sun and Bioshape cases, the transfer of land rights from villages to state has been permanent; no legal procedure exists in Tanzania for reversing this (Sulle and Nelson 2009). There have been strenuous efforts to address this problem in the Dar es Salaam High Court by a Tanzanian lands rights NGO which engages experienced high court lawyers as volunteers, but after several years of trying this has been to no avail. The community has been made worse off by a temporary project with effects that have so far proven impossible to undo and also without receiving adequate compensation or a substitute for the lost land that would enable them to pursue sustainable livelihoods in other ways. A summary of the social harms incurred and the degrees to which these are deemed reversible in the Bioshape case is given in Table 2.

One might claim that investors of bankrupt projects become victims of circumstance as much as the local villagers, and thus cannot be expected to make amends. There are some comments that should be made on this point. Sun Tanzania was part of a huge British multinational that could rather easily absorb its losses from the project, and the non-local staff members that had been working on the plantation were not left destitute. In the case of Bioshape, the firm's (very wealthy) investors were forgiven their debts in the Dutch legal bankruptcy procedure and have since gone on to take on other business challenges. The hired foreign management staff already found other wage jobs well before the bankruptcy took effect (Romijn 2011). The switch was not problematic for them to achieve, given their education, experience, skills and professional network. So, the severity of the social harm incurred by the investors and managers is not comparable to the impacts incurred by the local population. Indeed, one could question whether the investors and managers were harmed at all: reaching back to Feinberg's definition, it is not clear their interests were set back in any meaningful way, let alone wrongfully.

The loss of vital land resources is bound to affect the livelihood opportunities of future generations even more severely than the current one. Tanzania's population is growing rapidly, while climate change effects and structural over-utilisation are steadily reducing land productivity. Land pressures are steadily increasing as a result of these factors, as they are in many other parts of sub-Saharan Africa (von Braun et al. 2013). When projects like those of Bioshape and Sun-whether by design or by accident - are allowed to add to this already heavily stressed environment, crucial tipping points could be reached, inducing structural loss of social resilience: we should expect such projects to add to the uprooting of local communities in search of survival, aggravating rural-urban migration and destitution in urban slums, and the break-up of traditional ways of family and community life. Rural projects should be designed to attenuate such trends or at least avoid becoming sources of their aggravation.

Both the Bioshape case and the Sun Biofuels case show signs of reduced long-term social resilience due to deterioration of natural resource availability and increased insecurity of access and inadequate compensation for these losses: in the case of Kisarawe, the starting point was a community already under severe stress due to a degraded ecological system. Its chances of recovering from the Sun experience and its ability to adapt to the new situation in a way in which core social and spiritual values are preserved appear to be severely limited. In the case of Bioshape, the structural adverse consequences do not seem to touch upon spiritual values but emanate from the very large land area involved in the transfer and uncertainty over future access, the clear felling of woodland which was a major livelihood resource, the severe poverty of the local people in a depressed region, the long timescale involved in forest regeneration and the inertia of legal institutions. 


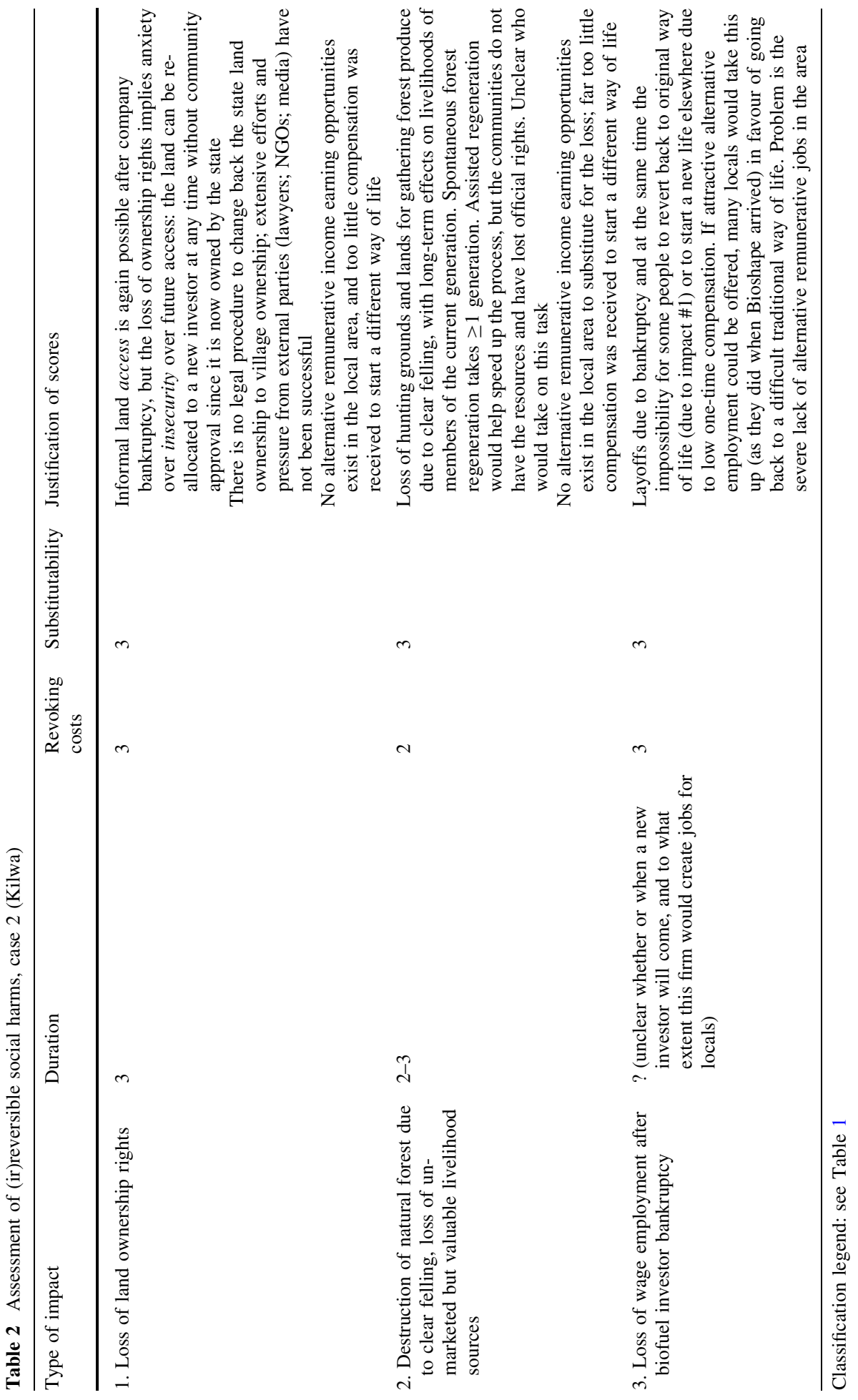


In both cases, actions could have been undertaken to turn irreversible into reversible harms or to increase their reversibility. First, there would have been value in the government giving out substantially shorter lease periods (a measure that Tanzania in fact implemented in 2012, but the current 33 years is still very long), legally requiring companies to draw up an exit strategy, making investment approvals conditional upon provisions such as deposits in a fund for eventualities and spelling out the details of compensation to be provided in case of financial trouble, thus mitigating potential harms (van Eijck et al. 2014). Companies can also be legally required to correct unforeseen negative effects from the lease, such as re-allowing villagers to access those parts of the leased land considered non-substitutable, such as neighbourhood water points and ancestral grave sites. Even better, the government could have insisted on arrangements in which local people retain their land rights and share in the benefits from the plantation as coowners; mandating that maintenance of adequate food supply and water access for local communities become essential parts of such investment deals (ibid.). A strict land zoning strategy and upper ceilings on the size of the leased land could also help to some extent (these two measures are in fact currently being implemented in Tanzania; Kiishweko 2012). Independent regulation of EIAs can also help, as can able, just and responsible implementation of resource governance guidelines (FAO 2012). All these strategies could remove potentially irreversible harms or turn them into reversible ones.

Following option value theory, there also would have been value in postponing fullscale implementation of large projects. Instead, one could have opted for a more cautious, gradual and flexible approach with pilot projects, which could have generated lessons and thus afforded space for course corrections along the way. Such a gradual approach should be grounded in more deliberative, democratic project organisation and management principles, so that collective learning by all concerned stakeholders can be allowed to happen through iterative social interactions (Hall et al. 2012; UNDP 2000). Participation and learning are precursors to resilience (Biggs et al. 2015). At the same time, we should also not be naive in promoting such deliberative processes as full-scale solutions. As observed by Borras Jr. and Franco (2010, p. 31), a decentralised negotiation process may even aggravate problems for the rural poor, because it is in the rural communities that the political and economic power of the dominant classes and groups are most entrenched.

\section{Conclusions}

In this paper we have investigated the notion of irreversibility and its ethical significance. We have argued that irreversible harms can be ethically problematic for several reasons, most importantly that they reduce the options for action open to a community, which may include foreclosure of opportunities for flourishing and survival as well as for responding and adapting to further detrimental changes (i.e. a loss of resilience). We have also formulated recommendations for policy-makers on how to deal with threats of irreversible harm. The application to the case of Tanzanian biofuel projects brings out that our framework is indeed useful for pointing out problematic social irreversibilities, as well as the key forces that produce them, and suggests a range of ways of countering them.

For further research and action, we suggest that the most pressing issue identified in this paper is that social harms are systematically undervalued, especially at the time when investments are being considered or just starting off. This was clearly illustrated in the Tanzanian biofuel story - the vantage point of the government and the investors who are 
supposed to weigh these effects is too dramatically different from the perspective of the local people. As one Tanzanian journalist put it, "It is hard for most people in the industrialised world to imagine the level of desperation that many Tanzanians experience" (Mutch 2010). In such complicated situations, coupled with a dominant neoliberal mindset, sheer lack of awareness and a complex institutional set-up, there are plenty of opportunities for Young's structural injustice to develop and become deeply entrenched. The consequences thereof became clearly manifest in the unequal negotiation positions and the ability of powerful players to twist the system to their benefit. Projects like the ones discussed here are no exception in poor countries with weak governance structures like Tanzania (Kiishweko 2012; Hall et al. 2015).

One possible way in which the undervaluation issue can be tackled is to further develop the notion of socio-ecological systems in sociology as well as in ethics. If this notion were to replace or accompany the classical notion of ecosystems in, e.g. environmental sciences, the methodological toolkit of this field might be adapted and applied to measuring and valuing social changes as well, especially those caused by environmental changes and vice versa. This could also inspire further relevant development in cost-benefit analysis, by for instance increasing the realism of ex-ante project impact assessments through improved valuation. While in the social sciences work on this is already being done in, e.g. political ecology and socio-ecological system analysis, there are still many opportunities for research on their interaction in ethics (e.g. Norton 2005).

There is, however, a limit on what even amended economic approaches can achieve. Their focus on monetary valuation and compensation reflects the tendency of the increasing commodification of natural resources within a neoliberal framework. This tendency, and the underlying value system that promotes it, should be viewed with a healthy dose of caution. As the Tanzanian case study shows, not only are people in rural areas vulnerable because they are constrained in how they can make use of their (little) money in a relatively undeveloped rural economy reliant on subsistence land use, economic approaches also fail to recognise the social, spiritual and political significance of the land that they depend on and that sustains them in so many ways (Sulle and Nelson 2009).

Let us note here that dissatisfaction with economic approaches has in the last decades given rise to numerous sustainability assessment (SA) methodologies (e.g. Singh et al. 2012). SAs have some advantages over (amended) economic approaches, most notably their use of a diversity of indicators, economic but also social and ecological, to provide a more versatile and nuanced instrument to evaluate policy approaches. However, SAs have weaknesses as well which we believe can be partly offset by including an explicit evaluation of (ir)reversibility. For example, while SAs can tell us whether one policy option is more or less sustainable (and in which dimensions) than another, Lancker and Nijkamp (2000, p. 114) argue that "a given indicator does not say anything about sustainability, unless a reference value such as thresholds is given to it". Lancker and Nijkamp define their critical threshold values as "values that cannot be exceeded without causing unacceptably high damage and risk to the environment" (ibid.). All threshold values in a socioecological system after which irreversible harm occurs to its communities would fit neatly into this category. Note, finally, that Lancker and Nijkamp's critical threshold values fill the same gap for SAs as Bishop's (1978) safe minimum standard does for cost-benefit analysis.

A second general drawback of SAs is that, as they are supposed to be objective scientific instruments for measuring sustainability, their indicators tend to be defined in isolation rather than in relation to others. Singh et al. (2012, p. 297), after making an overview of SA methodologies, conclude that most SAs tend to focus on one of three sustainability 
dimensions (social, ecological or economic) and that interrelations between those dimensions are most difficult to capture and reflect in measurements. Our relational notion of irreversible harm helps to bring these interrelations into view. This is not a trivial gain, as the tipping point beyond which an ecological system collapses may be different from the tipping point beyond which communities within a socio-ecological system are irreversibly harmed.

Another way in which irreversible social harms could be made more salient is by further investigation into the ethical relevance of maintaining sufficient options for action available, and how this could be achieved through "robust policies". While the capability approach currently is particularly good in pointing out salient issues, it could benefit from connecting further with the political ecology literature and the incorporation of notions such as resilience and irreversibility. In particular, now that the UN has the Millennium and Sustainable Development Goals high on its agenda, identifying and valuing those changes that could constitute irreversible social harms, and thus work directly and structurally against sustainable development, is part of a much-needed political and scientific discussion.

Acknowledgements Funding was provided by the Netherlands Organisation for Scientific Research (NWO) through its MVI research programmes "Biofuels: sustainable innovation or gold rush?" (Grant No. 313-99210 ) and "Developing and implementing smart grids in India" (Grant No. 313-99-307). The authors would like to thank Dr. Andreas Spahn, the other members of the Eindhoven Philosophy and Ethics research seminar and three anonymous reviewers for very helpful comments on earlier drafts of this paper.

Open Access This article is distributed under the terms of the Creative Commons Attribution 4.0 International License (http://creativecommons.org/licenses/by/4.0/), which permits unrestricted use, distribution, and reproduction in any medium, provided you give appropriate credit to the original author(s) and the source, provide a link to the Creative Commons license, and indicate if changes were made.

\section{References}

Adger, W. N., Dessai, S., Goulden, M., Hulme, M., Lorenzoni, I., Nelson, D. R., et al. (2009). Are there social limits to adaptation to climate change? Climatic Change, 93, 335-354.

Allison, H. E., \& Hobbs, R. J. (2004). Resilience, adaptive capacity and the 'lock-in trap' of the Western Australian agricultural region. Ecology and Society, 9(1), 3.

Arora, S., Romijn, H. A., \& Caniëls, M. C. J. (2014). Governed by history: Institutional analysis of a contested biofuel innovation system in Tanzania. Industrial and Corporate Change, 23(2), 573-607.

Arrow, K. J., \& Fisher, A. C. (1974). Environmental preservation, uncertainty and irreversibility. The Quarterly Journal of Economics, 88(2), 312-319.

Baggio, J. A., Brown, K., \& Hellebrandt, D. (2015). Boundary object or bridging concept? A citation network analysis of resilience. Ecology and Society, 20(2), 2.

Baker, S. (2015). Sustainable development (2nd ed.). London: Routledge.

Béné, C., Frankenberger, T. \& Nelson, S. (2015). Design, monitoring and evaluation of resilience interventions: Conceptual and empirical considerations. In IDS working paper 2015(459).

Béné, C., Newsham, A., Davies, M., Ulrichs, M., \& Godfrey-Wood, R. (2014). Review article: Resilience, poverty and development. Journal of International Development, 26, 598-623.

Benjamin, W. (1968). The work of art in the age of mechanical reproduction. In H. Arendt (ed.) Illuminations: Essays and reflections (H. Zohn, Trans.). London: Fontana Press.

Bergius, M. (2012). Large scale agro investments for biofuel production in Tanzania-Impact on rural households. Thesis, Institute of Development Studies, University of Agder, Norway.

Biggs, R., Schlüter, M., \& Schoon, M. L. (2015). Principles for building resilience. Sustaining ecosystem services in social-ecological systems. Cambridge: Cambridge University Press.

Bishop, R. C. (1978). Endangered species and uncertainty: The economics of a safe minimum standard. American Journal of Agricultural Economics, 60(1), 10-18.

Blaikie, P., \& Brookfield, H. (1987). Land degradation and society. London: Methuen. 
Blok, V. (2014). Look who's talking: responsible innovation, the paradox of dialogue and the voice of the other in communication and negotiation processes. Journal of Responsible Innovation, 1(2), 171-190.

Borras, S. M., Jr., \& Franco, J. (2010). Towards a broader view of the politics of global land grab: Rethinking land issues, reframing resistance. Amsterdam: ICAS/LDPI/TNI.

Brown, K. (2014). Global environmental change I: A social turn for resilience? Progress in Human Geography, 38(1), 107-117.

Bryant, R. L. (1998). Power, knowledge and political ecology in the third world: A review. Progress in Physical Geography, 22(1), 79-94.

Carrington, D. (2011). UK firm's failed biofuel dream wrecks lives of Tanzania villagers. The Guardian, November 30. http://www.theguardian.com/environment/2011/oct/30/africa-poor-west-biofuelbetrayal. Accessed September 29, 2016.

Chachage, C., \& Baha, B. (2011). Accumulation by land devaluation and labour devaluation in Tanzania. Dar es Salaam: HAKI ARDHI.

Claude, H. (1974). Option-values in the economics of irreplaceable assets. In Review of economic studies: Symposium on the economics of exhaustible resources, pp. 89-104.

Correljé, A., Cuppen, E., Dignum, M., Pesch, U., \& Taebi, B. (2014). Responsible innovation in energy projects: Values in the design of technologies, institutions and stakeholder interactions. In J. van den Hoven, E. J. Koops, H. A. Romijn, T. Swierstra, \& I. Oosterlaken (Eds.), Responsible innovation (Vol. 2, pp. 183-200). Dordrecht: Springer.

Costanza, R., de Groot, R., Sutton, P., Van der Ploeg, S., Anderson, S. J., Kubiszewski, I., et al. (2014). Changes in the global value of ecosystem services. Global Environmental Change, 26, 152-158.

Cotula, L. (2013). The great African land grab? Agricultural investments and the global food system. London: Zed Books.

Cotula, L., Dyer, N., \& Vermeulen, S. (2008). Fuelling exclusion? The biofuels boom and poor people's access to land. London: IIED.

Deininger, K., \& Byerlee, D. (2011). Rising global interest in farmland. Can it yield sustainable and equitable benefits?. Washington D.C: World Bank.

EC. (2009). Directive 2009/28/EC of the European Parliament and of the Council of 23 April 2009 on the promotion of the use of energy from renewable sources and amending and subsequently repealing Directives 2001/77/EC and 2003/30/EC Renewable Energy Directive. Official Journal of the European Union, L, 140, 16-62.

FAO. (2012). Voluntary guidelines on responsible governance of tenure of land, forests and fisheries in the context of national food security. Rome: FAO.

Feinberg, J. (1984). Harm to others. Oxford: Oxford University Press.

Franklin, S., \& Downing, T. (2004). Political ecology of vulnerability. Policy brief. Stockholm: Stockholm Environmental Institute.

Hall, R., Scoones, I., \& Tsikata, D. (Eds.). (2015). Africa's land rush. Rural livelihoods and agrarian change. Suffolk: Boydell \& Brewer.

Hall, A., Sulaiman, R., \& Ojha, H. (Eds.). (2012). Adaptive collaborative approaches in natural resource governance: Rethinking participation, learning and innovation. London: Routledge.

Hanser, M. (2008). The metaphysics of harm. Philosophy and Phenomenological Research, 77, 421-450.

Hansson, S. O. (2006). Informed consent out of context. Journal of Business Ethics, 63, 149-154.

Havnevik, K. (2011). Grabbing African lands for energy and food: Implications for land rights, food security and smallholders. In P. B. Matondi, K. Havnevik, \& A. Beyene (Eds.), Biofuels, land grabbing and food security in Africa, Chapter 1 (pp. 20-43). Uppsala: Zed Books.

Hickey, A., du Toit, A. (2007). Adverse incorporation, social exclusion and chronic poverty. In CPRC WP 81, School of Environment and Development, University of Manchester, Manchester.

Hillerbrand, R., \& Peterson, M. (2014). Nuclear power is neither right nor wrong: The case for a Tertium Datur in the ethics of technology. Science and Engineering Ethics, 20, 583-595.

Hodbod, J., \& Tomei, J. (2013). Demystifying the social impacts of biofuels at local levels: Where is the evidence? Geography Compass, 7(7), 478-488.

Hodbod, J., Tomei, J., \& Blaber-Wegg, T. (2015). A comparative analysis of the equity outcomes in three sugarcane-ethanol systems. Journal of Environment \& Development, 24(2), 211-236.

Humphrey, M. (2001). Three conceptions of irreversibility and environmental ethics: Some problems. Environmental Politics, 10(1), 138-154.

Illies, C. F. R., \& Meijers, A. W. M. (2009). Artefacts without agency. The Monist, 92(3), 420-440.

IPCC. (2014). Summary for policymakers. In C. B. Field et al. (Eds.), Climate change 2014: Impacts, adaptation and vulnerability. Part A: Global and sectoral aspects. Contribution of working group II to the fifth assessment report of the intergovernmental panel on climate change (pp. 1-32). Cambridge: Cambridge UP. 
Jonas, H. (1979/1984). Das Prinzip Verantwortung, Frankfurt am Main: Suhrkamp/The imperative of responsibility. In search of an ethics for the technological age, Chicago: The University of Chicago Press.

Kiishweko, O. (2012). Curbing Tanzania's "Land grabbing race”. Inter Press Service News Agency, 19 December. http://www.ipsnews.net/2012/12/curbing-tanzanias-land-grabbing-race/. Accessed September 29, 2016.

Kitabu, G. (2012). So much to lose than gain in foreign land investments. Farmlandgrab.org, 24 January. http://www.farmlandgrab.org/post/view/19939. Accessed September 29, 2016.

Lancker, E., \& Nijkamp, P. (2000). A policy scenario analysis of sustainable agricultural development options: A case study for Nepal. Impact Assessment and Project Appraisal, 18(2), 111-124.

Maltsoglou, I., \& Khwaja, Y. (2010). Bioenergy and food security. The BEFS analysis for Tanzania. Rome: FAO.

Manyena, S. B. (2006). The concept of resilience revisited. Disasters, 30(4), 433-450.

Martinez-Alier, J. (2005). The environmentalism of the poor: A study of ecological conflicts and valuation. New Delhi: OUP.

Matondi, P. B., Havnevik, K., \& Beyene, A. (Eds.). (2011). Land grabbing and food security in Africa. London: Zed Books.

McShane, K. (2007). Why environmental ethics shouldn't give up on intrinsic value. Environmental Ethics, 29(1), 43-61.

MEA. (2005). Ecosystems and human well-being: Synthesis. Washington, DC: Island Press.

Mill, J. S. (1859). On liberty. Reprinted in M. Lerner (ed.) (1961). Essential works of John Stuart Mill. New York: Bantam Books.

Msuya, T. S., Kidesgesho, J. R., \& Mosha, T. C. E. (2010). Availability, preference, and consumption of indigenous forest foods in the Eastern Arc mountains, Tanzania. Ecology of Food and Nutrition, 49, $208-227$.

Murphy, C., \& Gardoni, P. (2007). Determining public policy and resource allocation priorities for mitigating natural hazards: A capabilities-based approach. Science and Engineering Ethics, 13, 489-504.

Mutch, T. (2010). Jatropha biofuels: The true cost to Tanzania. The Ecologist, 15 February.

Næss, A. (1973). The shallow and the deep, long-range ecology movement. Inquiry, 16(1-4), 95-100.

Norris, F. H., Stevens, S. P., Pfefferbaum, B., Wyche, K. F., \& Pfefferbaum, R. L. (2008). Community resilience as a metaphor, theory, set of capacities, and strategy for disaster readiness. American Journal of Community Psychology, 41(1-2), 127-150.

Norton, B. G. (2005). Sustainability: A philosophy of adaptive ecosystem management. Chicago: University of Chicago Press.

Nussbaum, M. (2000). Women and human development: The capabilities approach. Cambridge: Cambridge University Press.

Peet, R., \& Watts, M. (Eds.). (1996). Liberation ecologies: Environment, development, social movements. London: Routledge.

Peterson, M. B., \& Spahn, A. (2011). Can technological artefacts be moral agents? Science and Engineering Ethics, 17(3), 411-424.

Phillips, N. (2013). Unfree labour and adverse incorporation in the global economy: Comparative perspectives on Brazil and India. Economy and Society, 42(2), 171-196.

Quétier, F., Regnery, B., \& Levrel, H. (2014). No net loss of biodiversity or paper offsets? A critical review of the French no net loss policy. Environmental Science \& Policy, 38, 120-131.

Romijn, H. A. (2011). Fieldwork notes from interviews with biofuel stakeholders in Tanzania.

Sandel, M. J. (2012). What money can't buy: The moral limits of markets. New York: Farrar, Strous and Giroux.

Schlimmer, S. (2016). Bureaucracy versus land grabbing? Replacing the state in a fashionable debate in Tanzania. Mambo, XIV(4), 1-4.

Schneider, L. (2006). Colonial legacies and postcolonial authoritarianism in Tanzania: Connects and disconnects'. African Studies Review, 49(1), 93-118.

Sen, A. (1992). Inequality re-examined. Oxford: Clarendon Press.

Sen, A. (2005). Human rights and capabilities. Journal of Human Development, 6(2), 151-166.

Silva-Castañeda, L. (2012). A forest of evidence: third-party certification and multiple forms of proof-A case study of oil palm plantations in Indonesia. Agriculture and Human Values, 29, 361-370.

Singh, R. K., Murty, H. R., Gupta, S. K., \& Dikshit, A. K. (2012). An overview of sustainability assessment methodologies. Ecological Indicators, 15, 281-299.

Smith, B. (2007). Annotated bibliography on social exclusion, adverse incorporation and chronic poverty. In CPRC WP 86, School of Environment and Development, University of Manchester, Manchester. 
Smith, A., \& Stirling, A. (2010). The politics of socio-ecological resilience and sustainable socio-technical transitions. Ecology and Society, 15(1), 11.

Spash, C. L. (1997). Ethics and environmental attitudes with implications for economic valuation. Journal of Environmental Management, 50, 403-416.

Stafford-Smith, M., Griggs, D., Gaffney, O., Ullah, F., Reyers, B., Kanie, N., et al. (2016). Integration: The key to implementing the sustainable development goals. Sustainability Science. doi:10.1007/s11625016-0383-3.

Stott, P. A., \& Sullivan, S. (Eds.). (2000). Political ecology: Science, myth and power. London: Arnold.

Sulle, E., \& Nelson, F. (2009). Biofuels, land access and rural livelihoods in Tanzania. London: IIED.

UN (1992). Report of the United Nations conference on environment and development, Rio de Janeiro, 3-14 June 1992.

UNDP. (2000). Capacity development: A UNDP Primer. New York: United Nations.

Valentino, S. (2011). Tanzania biofuel project's barren promise. IPS News, 9 March. http://www.ipsnews. net/2011/03/tanzania-biofuel-projects-barren-promise/. Accessed September 29, 2016.

van der Horst, D., \& Vermeylen, S. (2011). Spatial scale and social impacts of biofuel production. Biomass and Bioenergy, 35, 2435-2443.

van Eijck, J. A. J., Romijn, H. A., Smeets, E., Bailis, R., Rooijakkers, M. J. A. M., Hooijkaas, N., et al. (2014). Comparative analysis of key socio-economic and environmental impacts of smallholder and plantation based jatropha biofuel production systems in Tanzania. Biomass and Bioenergy, 61, 25-45.

Verbruggen, A. (2013). Revocability and reversibility in societal decision-making. Ecological Economics, $85,20-27$.

von Braun, J., Gerber, J., Mirzabaev, A., \& Nkonya, E. (2013). The economics of land degradation. In Working Paper 109, Center for Development Research (ZEF), University of Bonn.

Vulturius, G., \& Davis, M. (2016). Defining loss and damage: The science and politics around one of the most contested issues within the UNFCCC. Stockholm: Stockholm Environment Institute.

Wade, R. H. (2003). What strategies are viable for developing countries today? The world trade organization and the shrinking of 'development space'. Review of International Political Economy, 10(4), 621-644.

Walker, B. H., Holling, C. S., Carpenter, S. C., \& Kinzig, A. P. (2004). Resilience, adaptability and transformability in social-ecological systems. Ecology and Society, 9(2), 5.

Widengård, M. (2011). Biofuel governance: A matter of discursive and actor intermesh. In P. B. Matondi, K. Havnevik, \& A. Beyene (Eds.), Biofuels, land grabbing and food security in Africa (pp. 44-59). London: ZED Books.

World Bank. (2008). Putting Tanzania's hidden economy to work: Reform, management and protection of its natural resource sector. Washington D.C: World Bank.

WWF (2009). Biofuel industry study, Tanzania. An assessment of the current situation. Final version (March). World Wide Fund for Nature Tanzania Programme Office (WWF-TPO) Dar es Salaam, with support from WWF Sweden.

Young, I. M. (2004). Responsibility and global labor justice. The Journal of Political Philosophy, 12(4), 365-388.

Young, I. M. (2006). Responsibility and global justice: A social connection model. Social Philosophy and Policy, 23(1), 102-130. 